\title{
AUTHORITY OF TEACHER OF TECHNICAL AND COMPUTER SCIENCE BASED ON STUDENTS OPINION
}

\author{
Henryk Noga \\ Pedagogical University in Cracow, Poland \\ Tomasz Nesterak \\ Państwowa Wyższa Szkoła Zawodowa w Nowym Sączu, Poland \\ Maria Katarzyna Grzegorzewska \\ Poland
}

\begin{abstract}
Teacher profession has entails a huge responsibility. At work of a teacher, his character traits are key. Today, in the era of mass media, when in every home we can find a computer connected to the Internet, it is difficult to teacher to have the authority in students eyes. The main objective of this study is to learn about the level the teacher's authority of technical subjects - information technology.
\end{abstract}

Keywords: Technical and Information Technology Education, authority, study, student.

\section{Introduction}

The analysis of pedagogical literature and research results show that there is no ready-made suggestion according to which the teacher can build authority in the eyes of the student. For one person the supreme value is knowledge, for another appropriate way to communicate with others. This is due to their own, personal hierarchy of values, of what qualities or competencies students appreciate more from others. According to B. Dymara the biggest role in building the authority is love for the child. (Kaczor, 2002; Gumuła et al., 2014) state that, knowledge and professional skills are not enough, far much greater role is played by communication skills, teacher charisma, but especially his cognitive, emotional or aesthetic sensitivity (Tureková et al., 2014).

\section{The role of the teacher of technical - information technology in the information society}

Groving share of information technology in every area of life, forces the education system to change a role of the teacher (Prauzner, 2014; Pytel, 2016). 
Teacher must motivate, guide and encourage. Additional challenges arise before the teacher of technical subjects and information technology, arising from the phenomenon of ,pedagogical inversion”, which is mentioned in his work by M. Mead. (Mead, 2000) This is a situation when a student exceeds the knowledge and skills of their teacher. This phenomenon particularly is often found in the subjects related to computer science (Haskova et al., 2015). This is due, of course, with young people ways of learning who use electronic devices, computer or the Internet from the beginning of their lives. (Siemieniecka \& Siemieniecki, 2016).

Therefore, in the information society, the teacher of technical subjects and information technology is burdened with even greater responsibilities. In addition to implementing teaching programs, he should continuously introduce students the world of new technologies that will affect their daily life. Teacher alone is almost bound for ideal use of available modern solutions. Teacher build his authority on the basis of his high media competence, which is said by W. Strykowski. (Strykowski, 2005)

The role of a teacher of technical information technology has increased considerably thanks to the development of science and technology (Kosmala, 2009; Piaskowska-Silarska, 2012). Expert knowledge in electronic devices, advanced programs, build authority not only in the eyes of the students, but also other teachers, for which such media do not arise from the nature of the subject they teach. He must also be aware of support of his associates, for which the use of modern technologies are a huge barrier, and apply them in a much easier operation for improved learning outcomes (Tureková, 2014).

Based on a pedagogical literature, one can define the teachers authority, which is meant as respect, trust and esteem. The teacher who as authority is seen as guide in the personal difficulties, model worth to follow and person they can identify with. This is possible through genuine dialogue between teacher and students.

\section{Research methodology}

The research aim was to demonstrate what teachers of technology or IT qualities are important for the perception the teacher as authority. The aim was also to determine what other factors are related to the teacher functioning such as behaviour, communication or, the method of students assessment. The area of research were two junior high schools and two high schools. The study involved 241 students from middle and high schools from city Myślenice near Cracow. Classes were selected randomly. In each class were both students from the city of Myślenice, as well as from nearby villages. The studies were carried between students of two educational stages - Stage III (gymnasium, 13-16 years old) and Stage IV (high schools, 16-18 years old). The total number of students was 241: 
- Public Gymnasium in Jawornik them. Ks. Jan Twardowski - 52 students;

- $\quad$ Gymnasium No. 1 for them. Julius Slovak Myslenice - 67 students;

- $\quad$ Schools them. Andrew Średniawski in Myslenice - 63 students;

- $\quad$ High Schools them. Titus Chałubińskiego in Myslenice - 59 students.

The number of respondents divided by stage of education:

- $\quad$ III stage of education - 119 students

- $\quad$ IV stage of education - 122 students.

67 students of the fourth stage of education comes from rural areas, while 55 people from the town, most often from Myślenice. Among the surveyed students with the third stage of education, the relationship looks like. $51.3 \%$ of the students come from rural areas and the remaining 58 people are inhabitants Myslenice that is close near Krakow.

\section{Understanding by students a concept of authority}

The question about knowledge of the concept of authority was to investigate the level of knowledge about a given idea. Open question: „How do you understand the concept of authority?" Allowed to get different answers. The most common response was to say that the authority, is a person worthy of emulation. This or very similar (eg. „Role model”) answers granted by 178 surveyed people, represented by $74 \%$ of total respondents. Considerably less frequently appeared an answer stating, that the authority is a person which possesses a social recognition, respect, (eg. „A person worthy of respect, respectable person”). This nature of the replies appeared in only $15 \%$ of the respondents (36 people). Other answers in the number of $27(11 \%)$ must be allocated to the category not suitable for evaluation and grouped as other.

\section{The status of teachers of technical subjects and information technology}

Interviewed students were answering more questions, they filled closed question about teacher of technical subjects and information technology, is or is not authority for them. Students opinions of a teacher of technical and information technology came out as negative - as many as 202 people have recognized that the teacher / have no authority for them. $16 \%$ (39) of respondents believed that teacher of these subjects is authority for them.

Presenting the results for the various stages of education may be drawn interesting conclusions. Considering only respondents of third stage of education, 31 people ( $26 \%$ of the surveyed group of high school students), stated that a teacher of technical subjects and information technology is authority for them. In 
Henryk Noga, Tomasz Nesterak, Maria Katarzyna Grzegorzewska. Authority of Teacher of Technical and Computer Science Based on Students Opinion

addition, it is worth noting that all 31 people who commented positively on this issue are men.

Table 1 Intrinsic features that affect the perception of teachers of technical subjects and information technology as an authority by the respondents of third stage of education

\begin{tabular}{|c|c|c|}
\hline Responses & $\begin{array}{c}\text { Number of responses associated } \\
\text { with the group (up to 31) }\end{array}$ & $\begin{array}{c}\text { Percentage response } \\
\text { [\%] }\end{array}$ \\
\hline personality features & 31 & 100 \\
\hline substantive knowledge & 25 & 80 \\
\hline $\begin{array}{c}\text { skilful transfer of } \\
\text { knowledge }\end{array}$ & 17 & 55 \\
\hline other features & 3 & 10 \\
\hline
\end{tabular}

The results illustrate that students of third stage of education participating in the study, as a feature that determined the perception of teachers of technical subjects and information technology unanimously chose those association with personality or, eg. Justice, conscientiousness, compassion. $80 \%$ indicated that the features associated with substantive knowledge contributed greatly to this perception. More than half of the 31 respondents indicated that skilful transmission of knowledge through teaching of technical subjects and information technology influenced mostly their decisions. The group of ,other characteristics” should be attributed to answers related to the external appearance.

88 middle school students shows a negative opinions with respect to teachers of technical subjects and information technology as an authority. As in the previous case, the answers received, should be grouped together in order to achieve transparent results.

Table 2 Features that don't affect perception of teachers of technical subjects and information technology as an authority by respondents of third stage of education

\begin{tabular}{|c|c|c|}
\hline Responses & $\begin{array}{c}\text { Number of responses } \\
\text { associated with the group } \\
\text { (up to 88) }\end{array}$ & $\begin{array}{c}\text { Percentage response } \\
\text { [\%] }\end{array}$ \\
\hline $\begin{array}{c}\text { negative personal } \\
\text { qualities }\end{array}$ & 86 & 98 \\
\hline merit lacks & 45 & 51 \\
\hline $\begin{array}{c}\text { skillful transfer of } \\
\text { knowledge }\end{array}$ & 32 & 37 \\
\hline other negative features & 9 & 10 \\
\hline
\end{tabular}

Students who decided in a closed question that teachers of technical subjects and information technology are not authority for them, as previously almost 
unanimously $(98 \%)$ decided that these components are negative personality features such as being unfair, impatience. 45 of 88 respondents of in this group have indicated that the negative reception of teachers shortages affect his school subject. $37 \%$ points out weaknesses in the knowledge transmission. Other negative attributes were mentioned by 9 people.

122 Of submitted for examination respondents of secondary schools, 8 indicated that teachers in technical subjects and information technology feel respect. Almost $94 \%$ of respondents (114) indicated the lack of authority.

Table 3 Personal features affecting the perception of teachers of technical subjects - and information technology as an authority by respondents of the fourth stage education

\begin{tabular}{|c|c|c|}
\hline Responses & $\begin{array}{c}\text { Number of responses } \\
\text { associated with the group (up } \\
\text { to 8) }\end{array}$ & $\begin{array}{c}\text { Percentage response } \\
{[\%]}\end{array}$ \\
\hline personal features & 5 & 62 \\
\hline merit knowledge & 8 & 100 \\
\hline $\begin{array}{c}\text { skillfull transfer of } \\
\text { knowledge }\end{array}$ & 1 & 12 \\
\hline other features & 0 & 0 \\
\hline
\end{tabular}

Students of secondary schools who responded affirmatively on the status of the teacher's authority and technical subjects and information technology have pointed substantive knowledge (100\%) as the main factor that determined their selection. Personality traits of teacher gained recognition in 5 respondents, while the ability to transfer knowledge was pointed out by only one student.

Table 4 Personal features that are affecting negatively the perception of teacher is not technical subjects - and information technology as an authority by respondents of the fourth stage education

\begin{tabular}{|c|c|c|}
\hline Responses & $\begin{array}{c}\text { Number of responses } \\
\text { associated with the group (up } \\
\text { to 114) }\end{array}$ & $\begin{array}{c}\text { Percentage response } \\
\text { [\%] }\end{array}$ \\
\hline $\begin{array}{c}\text { negative personal } \\
\text { features }\end{array}$ & 90 & 79 \\
\hline merit lacks & 92 & 80 \\
\hline $\begin{array}{c}\text { lack of abilities to } \\
\text { transfer knowledge }\end{array}$ & 75 & 66 \\
\hline other negative features & 31 & 27 \\
\hline
\end{tabular}

Students of IV stage educational, who decided that currently teacher of technical subjects and information technology have no authority, almost equally 
was pointed out the crucial negative features, associated with personality (79\%) and substantive deficiencies ( $80 \%$ ). In $66 \%$ of responses-vocational indication on incompetent of knowledge transfer and communication. Significant high indication of negative features of group of „others”, oscillating around $27 \%$.

The surveyed students from both stages of education pointed out that personal qualities $(91.7 \%)$ and theoretical knowledge $(84.2 \%)$ are crucial for the teacher of technical and information technology. A smaller proportion of respondents pointed out the skilful knowledge transfer $(64.3 \%)$. Other crucial features indicated by the surveyed students occurred in $20.7 \%$ of the responses. Taking into account only the various stages of education, the results are similar. Students of IV educational stage only more attention to the skilful knowledge transfer (92 people) compared to younger colleagues (63 people).

\section{Assessment of participant of research and teacher of technical - and information technology}

Over $60 \%$ of respondents indicated that teachers technical skills are mediocre. $26.1 \%$ of respondents threated positively these (good or very good) skills. Negative skills were referred by 33 respondents.

More than $3 / 4$ of the surveyed students from secondary schools estimated average teacher skills of technical and information technology. $18 \%$ of participants rated these as good or very good, $6 \%$ have no positive opinion about the teacher skills.

132 of respondents answered that teachers exceeds the technical and information technology skills. $32 \%$ of respondents said that they do not have the skills. $13 \%$ of respondents had no opinion.

\section{Discussion}

The teaching profession is very unique. This is due to the activities undertaken by the teacher during teaching and through education process, which involves great responsibilities. The teacher has a huge impact on young people. $\mathrm{He}$ shapes their worldview, recognizes their talents. With incurring huge responsibility involves the need for a rich features associated not only with a wide knowledge of the subject of education, but also education and psychology.

The teachers who seek a status of teacher must meet a number of conditions. In addition to previously mentioned professional competence they must have the necessary personal qualities that will win the acclaimaton in the students eyes. Acquiring the status of teachers in the eyes of the student becomes increasingly challenging in modern times. Mass media, which have a huge impact on shaping 
views of young people, create other patterns of behaviour than those preferred and presented by education.

Even more challenging is formed before the teacher of technical and information technology that at times the information society bears even more responsibility than a decade ago. The labour market and everyday life, where modern technologies require knowledge of new devices and technology, usually based on some kind of operating systems (Ptak, 2013; Pytel et al., 2012). This is what the school should give direction and shape their development, help in choosing a profession. At a time when science and modern technology meet at every step, the teacher of technical subjects and information technology should help the student in ,serving society , in a changing world.

The present study sought to bring the issue of the teachers competence and the teaching profession. In addition, efforts were made to bring the problems connected with the authority of teachers, referring to use the traditional definition of modern times.

The aim of the study was to determine the definition of knowledge and the level of the teacher's authority of technical and information technology among students of III and IV educational stage. In my research I draw attention to the four main issues - knowledge issues of authority, to know whether and to what extent there is authority of the teacher of technical and information technology, identify the opinions of students about the requirements in relation to teachers of these subjects and opinions about their skill and features.

The results on the knowledge of authority allowed to create following conclusions:

- $\quad 74 \%$ of respondents identified the concept of authority with a role model, and only $15 \%$ have connected the issue of the authority of a person worthy of respect.

- $11 \%$ of respondents replied no logical sense, which may indicate respondents immaturity.

The results of studies regarding the occurrence of the teacher's authority of technical and information technology illustrate that:

- $\quad 202$ out of 241 respondents, representing up to $84 \%$ does not recognize the teacher of technical and information technology as the authority. Only $16 \%$ of respondents claim that the teacher is the authority for them. Despite the low indication of the presence authority, one will notice differences include the division that was in these educational stages. Among middle school students teacher of technical - and information technology as authority has in more than a quarter of respondents. This rate drops significantly, taking into account only respondents from fourth stage of education - is just $6.6 \%$. 
- Instructive conclusions can be drawn by teachers and students, analysing the characteristics mentioned by the students that flow into the status of a teacher. The following number of respondents from the third stage of education identified negative features that affect the positive reception of teachers: 31 personal qualities, 25 substantive knowledge, and 17 the skilful knowledge transfer. The negative reception of teachers at the following number of respondents have beeb caused by 86 - personal qualities, 45 - knowledge lacks, 32 incompetent knowledge transfer. The following number of respondents from the fourth stage of education pointed out negative features that affect the positive reception of teachers: 5 personal qualities, 8 substantive knowledge, and 1 the skilful knowledge transfer. The negative reception of teachers at the following number of respondents have caused 90 - personal qualities, 92 - knowledge lacks, 75 incompetent knowledge transfer.

Students of III and IV educational stage asked about the desirable qualities in a teacher of the technical - informational technology responded in a similar way, paying attention mainly to the personal qualities $(91.7 \%)$, theoretical knowledge $(84.2 \%)$. Students of III stage of education in a smaller extent, drew attention to the characteristics associated with skilful transfer of knowledge (63 people 119).

Respondents asked about skills of teachers in the vast majority (60.2\%) classified them as average. $26.1 \%$ rated them as good or very good. Low or very low - is an assessment of 33 respondents.

- Taking into account the distribution for each stages of educational, positive assessment (average, good, very good) are students of upper junior schools evaluated it better (94\%) than gymnasium (87\%).

- The surveyed students asked to compare their abilities with teachers, 55 $\%$ assessed their abilities better. $32 \%$ of respondents felt that teachers have more the technical and information technology abilities. $13 \%$ of respondents have no opinion.

- Regarding the results obtained in the last question, to the division between III and IV stage of education, the gymnasium students have better opinions on their skills $-64 \%$ of high school students believe that the level of skills is higher than the teacher. In secondary schools the percentage of such indications does not exceed $50 \%$.

\section{Conclusions}

To summarize all the results one come to the conclusion that students have a general understanding of the concept of authority, but its description is limited 
to one formulation, which is definitely not enough. The level of indications about the teacher's authority of technical and information technology is very low. This may be due to many reasons. Young people are greatly affected by the mass media, peer groups, no have seek authority among teachers, only in television and the Internet. The lower level of authority indicated in the fourth stage of education, may indicate that older students do not have such respect of teachers like in earlier years, which may well be associated with the period of adolescence Additionally the reason for such result may be rare competence of teachers in these subjects, who according to posted answers are often unjust, biased, impatient. The reliability of this response is difficult to determine because it required a number of hours observing them in schools where the study was conducted at the class technology, computer science. While the desirable characteristics of a teacher mentioned by junior high school students based on personality, it shows a tendency that the older students require extensive technical knowledge, as evidenced are the results of this study. Guideline for teachers of technical and information technology who wish to obtain status of a teacher, especially in secondary schools can be important role of theoretical knowledge in the process. Gaining authority among of students, who evaluate the knowledge of teachers as usually average, and their abilities evaluate higher than the learner, it is a very difficult task. For teachers of any school subject, personal qualities are essential, as is obvious, but for the teacher of technical and information technology, just as important, if not more important, is to have the knowledge that will surprise, interested young people, because the social changes, and the requirements of employers are moving in the direction of a wide technological knowledge. A student who since a young age can be fluent in the computer needs to acquire knowledge of the technical and computer science in up to a concentrated version. In another case, a teacher of technical subjects and information technology will never be able to counted as authority in the eyes of the student.

\section{References}

Gumuła, S., Pytel K., \& Piaskowska-Silarska, M. (2014). Polemical remarks to the claim that carbon dioxide strengthens greenhouse effect in the atmosphere. Polish Journal of Environmental Studies, No 1.

Haskova, A., Turekova I., \& Depesova, J. (2015). Quality Training of Future Professionals in Occupational Safety and Health Conference. 6th LUMEN International Conference on Rethinking Social Action Core Values Location: Iasi, Pages: 645-650. Date: APR 16-19, Sponsor(s): LUMEN.RETHINKING SOCIAL ACTION. CORE VALUES. ROMANIA.

Kaczor, T. (2002). Autorytet nauczyciela we współczesnej polskiej szkole .Dyrektor szkoły, miesięcznik kierowniczej kadry oświaty, nr 12, s. 17.

Kosmala, J. (2009). Edukacja w społeczeństwie informacyjnym. Wydawnictwo im. Stanisława Podobińskiego Akademii im. Jana Długosza, Częstochowa. 
Henryk Noga, Tomasz Nesterak, Maria Katarzyna Grzegorzewska. Authority of Teacher of Technical and Computer Science Based on Students Opinion

Mead, M. (2000). Kultura i tożsamość - Studium dystansu międzypokoleniowego. s.23. Wydaw. Naukowe PWN, Warszawa.

Piaskowska-Silarska, M. (2012). Analiza możliwości pozyskania energii z odpadów komunalnych. Polityka Energetyczna, tom 15, zeszyt $2 / 2$ s. 325-336. Wyd. IGSMiE PAN. Kraków.

Prauzner, T., \& Ptak, P. (2014). Analiza parametrów pracy wybranych czujników pola magnetycznego. Przegląd Elektrotechniczny, nr 12/2014, s. 273-276.

Ptak, P., \& Prauzner, T. (2013). Badania czujników detekcji zagrożeń w systemach alarmowych. Przeglad Elektrotechniczny, 2013 nr 10/2013, s. 274-276.

Pytel, K., Jaracz, K., \& Gumuła, S. (2012). An impact of chosen construction parameter and operating conditions on the quality of wind turbine energy generation. $\mathrm{s}$. 592-595.13 ${ }^{\text {th }}$ International Carpathian Control Conference (ICCC), Rzeszów.

Pytel, K., Piaskowska M., \& Migo P. (2016). Teaching bioscience in promary and middle school and children's ecological awareness, Education, Society, Integration, Volume II. s. 298, Rezekne.

Tureková, I., Depešová, J., \& Bagalová, T. (2014). Machinery risk analysis application in the system of employee trainin., Applied Mechanics and Materials, Volume 635-637, Pages 439-442, 4th International Conference on Advanced Design and Manufacturing Engineering, ADME 2014; 26 July 2014 through 27 July 2014; China.

Siemieniecka, D., \& Siemieniecki, B. (2016). The horizons of cognitive pedagogy. Society. Integration. Education, proceedings of the International Scientific Conference, May 27th-28th, s. 231-240, Volume I, Rezekne.

Strykowski, W. (2005). Kompetencje współczesnego nauczyciela. Neodidagmata 27/28, Poznań. 